\title{
The Great Mother: A Psychoanalytical Analysis of the Magna Mater In Two Novels
}

\author{
Dr. Wahaj Unnisa Warda
}

\begin{abstract}
Sigmund Freud formulated the theory of "Oedipus Complex", Erich Newmann came forth with "The Great Mother or the Magna Mater" based on Carl Jung's Theory of the Archetype and the Mother Complex, which charts the mental processes of women's psychological development. Two novels are analysed based on the given psychoanalytical theories the first a British novel "Sons and Lovers" by D.H. Lawrence and the other Australian "The Thorn Birds" by Colleen McCullough. Both novels have two brothers who become the focus of their mother's attention and the overbearing mother's control clashes with their identities, which results in death or fallout from society. The characters' personal conflicts reveal encrypted truth.
\end{abstract}

Key words- Sigmund Freud, Carl Jung, Archetype, Erich Newmann, D. H. Lawrence, Sons and Lovers, Colleen McCullough, The Thorn Birds.

\section{INTRODUCTION}

The first novel is a British novel Sons and Lovers by D.H. Lawrence. The male siblings are William and Paul Morel they have a brother and a sister, they live with their mother Gertrude Morel and father Walter Morel. The other an Australian novel The Thorn Bird by Colleen McCullough. The mother is Fee ( Fiona) Cleary and the sons are Frank (Francis) Cleary and Stu (Stewart) Cleary. Each of the characters trace their affection to one parent, their mother. Though they have other siblings both male and female, they and their mothers share a special bond very different to others. The mother- son relationship can be analysed based on the psychoanalytical theories of Sigmund Freud, Carl Jung and Newmann, by doing so we see that the odd bond is not one sided but reciprocal. Freud's theory interprets what the sons feel for the mother which is very different from normal son- mother affection. Newmann's Great Mother Illustration inspired by Carl Jung's theory about the Mother Complex and of the maternal psychological condition can be applied to the female characters to fully understand what leads the two mothers to rely so heavily upon their first born and later on the second favourite son, the reader constructs an interpretation for disparate elements. The sons of both novels develop from young adults, and have witnessed passive resistance, physical abuse, mental or verbal violence. Both the novels have been written around the same period sharing a common timeline at the start of the twentieth century, and haven't been yet examined together by scholars Shoshana Felman describes $(1995,46)$ "how the situations illuminate the understanding of the testaments allowing for the readers to identify intersections between literature, autobiography, and history each tied up with the act of bearing witness". This paper first explains both Freud's and Newmann's psychoanalytical theories which explain the Oedipus Complex- understanding of the son's psychology and the Magna Mater- understanding of the mother's mind, the mother's driving force based on the theory. Finally, the complex nature of the mother-son relationship is analyzed in the two stories.

\section{Psychoanalytical theory:}

The maternal archetype as suggested by Newmann has different aspects that manifested in different images, for example, the terrible aspect and the life-giving, "kindly" aspect of an 
archetype appear in diverging images. But on the other hand, the terribleness of one archetype , e.g., the Terrible Mother, is expressed in other symbols than that of another archetype, e.g., the Terrible Father. According to Freud, the child gets to the phase of genital primacy around age five, at which time the Oedipus complex demonstrates itself. To put it in simple words, the Oedipus complex originates from the boy's insentient competition with his father for the affection of his mother. Freud hired the term from the Oedipus the Rex a classic play written by Sophocles in which the hero unknowingly assassinates his father and marries his mother. This competition for the love of mother is described in The Ego and the Id, as follows:

.. . the boy deals with his father by identifying himself with him. For a time these two relationships [the child's devotion to his mother and identification with his father] proceed side by side, until the boy's sexual wishes in regard to his mother become more intense and his father is perceived as an obstacle to them; from this the Oedipus complex originates. His identification with his father then takes on a hostile coloring and changes into a wish to get rid of his father in order to take his place with his mother. Hence forward his relation to his father is ambivalent it seems as if the ambivalence inherent in the identification from the beginning had become manifest. An ambivalent attitude to his father and an object-relation of a solely affectionate kind to his mother make up the content of the simple positive Oedipus complex in a boy. (27-22)

It can be understood that when a woman of character and refinement gets married into the lower class, because she has come down in her life has no satisfaction. Because she had a passion for her husband, children are born. But the problem arises when the sons grow up she selects them as lovers, first the eldest and then the second. These sons' when they reach manhood cannot love because their mother's hold is the strongest power in their lives. This was summed up by Lawrence himself in one of his letters to Edward Garnett on 12 November 1912 about Sons and Lovers.

These sons are urged into life by their reciprocal love of their mother - urged on and on. But when they come to manhood, they can't love, because their mother is the strongest power in their lives, and holds them. It's rather like Goethe and his mother and Frau von Stein and Christiana - As soon as the young men come into contact with women, there's a split. The split kills him, because he doesn't know where he is. The next son gets a woman who fights for his soul - fights his mother. The son loves his mother - all the sons hate and are jealous of the father. The battle goes on between the mother and the girl, with the son as object. The mother gradually proves stronger, because of the ties of blood. The son decides to leave his soul in his mother's hands, and, like his elder brother go for passion. He gets passion. Then the split begins to tell again. But, almost unconsciously, the mother realizes what is the matter, and begins to die. The son casts off his mistress, attends to his mother dying. He is left in the end naked of everything, with the drift towards death.

Paul wins art prizes but William's winning the sporting trophy was far more important to Mrs. Morel. The sons live through their mother and she lives through them. She feels satisfied that her sons were perfect, she had fulfilled her maternal duty well, she had brought them up single-handedly into winners and not failures like their father. With the death or absence of a sibling the other son gets a chance to fill in the void left in the mother's heart, with William's death Mrs. Morel moves away from all of her family even Paul, but when Paul falls ill she cares for him and he secures the special place that once belonged only to William. Whereas the other pair Frank and Stu lacked these opportunities at socializing in the outback Fee took tremendous pride at being the mother of son. Frank always felt elated after his wrestling match victories it was during one such occasion that Paddy utters the dark secret of Frank's 
parentage after which Frank leaves to join a wrestling troop, resulting in killing a man and him being imprisoned for life at hard labour. Frank's running away from home brings Stu closer to his mother as he was the only one who totally took her nature both in looks and silence. Paddy had viewed Frank as a Jonas who forever had destroyed and hung like a dark shadow over his family's complete joy, did not feel that way towards Stu as Stu lacked the violence and fierceness. The control the mother practiced over the son does not bring any benefit it is this control that leads to the downfall of her best-loved son Frank. In Thorn Birds the awareness of her grip on her son was what restrained Frank for years preventing him from leaving her. It was only when Paddy had told Frank in a fit of rage the reality of Frank's parentage that Frank knew he could break all bonds and be gone. But his parting was not an easy one for him as he left with the burden of guilt that all the years he had felt it was Paddy who had been restraining his mother holding her down but he realized that it was him, all along. His existence and the need to give him the legitimacy that had tied her to Paddy. A man whom Frank had thought was unworthy of Fiona neither in status or virtuosity, had been responsible in giving him legitimacy and making Fee respectable in the eyes of society was too much for him to bear.

The only time that the sons' physical feelings for the mother surface is when the sons refuse to believe that the mother could be anyone less than that to be revered like the virgin Mary, the sons directly ask the mother not to sleep with their father. Freud describes the child's conflict is between the desire for union (incest) and the impossibility of union enforced by the father's threat of castration, psychologists Abraham and Torok begin with the premise-based on the life- situation - that the mother-child union already exists. The child's conflict in terms of the desire to remain faithful to the mother in an obsolete state of in differentiation and the desire for detachment from the mother in a forward- in a quest for individuality. In Thorn Birds Frank always felt that his mother was far superior to her husband in every sense, be it appearance, behavior or personality, he felt his father was the source of his mother's wasted existence. And carried out miserable acts forcing her to have more children which her feeble body no longer could withstand.

"He had no right! He should have left you alone!" Frank hissed, wiping a fleck of foam from the corner of his trembling mouth. "It isn't dirty," she repeated wearily and looked at him from her clear tired eyes as if she had suddenly decided to put shame behind her forever. "It's not dirty, Frank, and nor is the act which created it." This time his face reddened. He could not continue to meet her gaze,...(124)

In Sons and Lovers Paul overdoses his mother with morphine, he does so with the consent of his sister Annie, because it was agonizing for them to take care of their ailing mother and also to end their mother's misery. The act of Paul taking his mother's life is a reversal of Oedipus Complex where he doesn't kill the "terrible father" but kills the focus of his affection. It is only in her death does Paul's express his true feelings for her, the feelings that he had pent up for so long in his stroking and kissing her dead body he finally lets out what he had been unable to do so during her lifetime.

Camille Paglia summarises four mental stages in women's psychological development theorized by the German theorist Erich Newmann in his book "The Great Mother: An Analysis of the Archetype, a study of the Magna Mater". The first stage as the undifferentiated matrix or psychic unity where the ego and the unconscious are still fused. He called this stage matriarchal and symbolized it as the uro boros, an ancient symbol of a snake biting its tail, both devouring and giving birth to itself an image of either solipsism or fertility. The second stage is the spiritual invasion and domination by The Great Father archetype associated with rationalism and monotheism who is 
perceived as the destroyer or rapist. The third stage embodies the masculine in a normative individual, a rescuing hero who liberates the young woman from the controlling father but yokes her to a conventional marriage under new male authority. Sex roles are polarised with masculinity and femininity mutually elusive. The fourth and final stage has feminist implications here the mature woman discovers her authentic self and voice. As she borrows from the masculine, sex roles are blurred and the decline of the matriarchal canon.

Gertrude (Choppard) Morel is described as the refined daughter of a burgher family who met up with a rough miner at a Christmas dance. Their relationship was characterized by passion, Gertrude initially was passionately in love with Walter Morel but slowly grew apart. The main attraction was that he was different from her own father whose overbearing behavior towards her mother she found intolerable. Gertrude made herself believe that if one was a man one could do anything. Fee (Fiona) Cleary was born into aristocracy but married to a farmhand Paddy (Padriac) Cleary as she had disgraced the family, her feelings were hidden away by non expression and silence her thoughts were exclusively her own. The first and second phases of Newmann's theory are applicable to both Gertrude and Fiona as being young and in love. Gertrude always treasured the Bible gifted by John Field and had valued his friendship, but had married a man lower to herself as she was lead on by the false dreams, Fiona had fallen in love with a much older married man and had his son out of wedlock, defying a family of eleven brothers. Paddy had married her as he had been offered a handsome sum of money to take her away. The third phase where the husband is the protector and rescuer, the female is pushed from one matriarchal authority to a different authority which may or may not be accepted. Gertrude with the birth of her first son William refused to let him become like her miner husband, she was both physical and vocal in her protests. She fully understood her folly upon finding unpaid bills she also learned that the house they lived in belonged to her mother in law and that her husband owed her a lot of money. Gertrude became disillusioned, cold and condescending towards her husband. She felt isolated from her husband who had started spending more and more time after work at the bar and gambling away his earnings. They were constantly fighting about money causing her to turn towards her firstborn son William. Whereas the other mother Fee had reacted in quite the opposite she chose a deep and impenetrable silence, though Paddy was poor he was a hard worker with no bad habits all the money he earned came home to his family. Fiona chose a dour calm and buried herself in her housework which was a pretext for her to be left alone with her memories, this ritual was broken only in the sole presence of her firstborn Frank. Frank knows her better than Paddy, she was more demonstrative with Frank than she was with her husband, preferring his company at the end of the day then that of Paddy's.

Newmann's primordial image or archetype of the Great Mother liberation of the male consciousness from the feminine maternal unconscious is a hard and painful struggle for all mankind, it is clear that the negative elementary character of the Feminine does not spring from an anxiety complex of the "men,". Both women were disillusioned in love and the men in their life sense it and spare no attempt at castrating the favorite son Fee loved an older married man and Gertrude by John Field. Fee had a son who reminded her of the man she loved and took great comfort in him, Paddy was aware of the fact that Frank was a living reminder but he also knew that he and all his children put together were not of the same value to Fee as Frank alone. To make sure Frank was always within his limit Paddy was exceptionally strict with him making him work as a black smith so that it would vent off his physical rage his vicious streak, a streak Frank was successful in concealing from his mother but not from his father. Frank was a born fighter who had proven his physical strength to the best of crowds. When Frank ran away from home to enlist for the army Paddy had him brought back in 
disgrace and added insult to abuse by commenting that someone of Frank's short stature could not enlist. Walter Morel though has a legitimate son to tease his wife cuts off William's hair while she was asleep this act made the rift between husband and wife permanent.

These acts lead to Newmann's fourth and final phase of feminist implications here the mature woman discovers her authentic self and voice. Mrs. Morel loves the affection her sons indulge upon her. Mrs. Morel knows of her sons' interest in other girls and eyes them suspiciously when William sent her a picture of Ms. Western to seek his mother's approval, she refused to encourage any of the girls Mariam or Clara when Paul was interested in them, she believed they were only using her sons and looked down on them. Fee was fully aware that in the barren, isolated outback her sons were hers alone.

\section{CONCLUSION}

In light of the psychological theories both the novels reverse relationships- the image of not only the son changes but the maternal revered image changes forever as described by Newmann: dark half of the black-and-white cosmic egg representing the Archetypal Feminine engenders terrible figures that manifest the black, abysmal side of life and the human psyche. Just as world, life, nature, and soul have been experienced as a generative and nourishing, protecting and warming Femininity, so their opposites are also perceived in the image of the Feminine; death and destruction, Thus the womb of the earth becomes the deadly devouring of the underworld, and beside the fecundated womb and the protecting cave of earth and mountain gapes the abyss of hell, the dark hole of the depths, the devouring womb of the grave and of death, of darkness without light, of nothingness.

\section{References:}

Abraham, Nicolas, Maria Torok, and Nicholas Rand. (1984). "A Poetics of Psychoanalysis: 'The Lost ObjectMe.”' SubStance 13 (2): 3-18. http://jstor.org/stable/3684812.

Aldington Richard (1968) Selected Letters D. H. Lawrence Penguin Books Ltd. Harmondsworth, Middlessex, England .

Dobie, Elizabeth Ann. "Interweaving Feminist Frameworks." The Journal of Aesthetics and Art Criticism 48, no. 4 (1990): 381-94. doi:10.2307/431575.

Farr, Judith, ed. 1970.Twentieth Century Interpretations of Sons and Lovers. New Jersey: Prentice-Hall, Inc.

Felman, Schoshona.1992. Testimony: Crises of Witnessing in Literature, Psychoanalysis and History. Routledge.

Freud, Sigmund. 2011. The Oedipus Complex: A Selection of Classical Articles on Sigmund Freud's Psychoanalytical Theory. Wolfenden Press.

Jung. C.G, Collected Works of C.G. Jung: The Archetypes and the Collective Unconscious” Translated by R.F.C. Hull, Princeton University Press. 1969.

Kelsey N. (1991.) Sons and Lovers. In: D. H. Lawrence: Sexual Crisis. Macmillan Studies in Twentieth-Century Literature. Palgrave Macmillan, London.

Lawrence, D. H. 1992. Sons and Lovers. New York: BCA.

https://www.bu.edu/arion/files/2010/03/Paglia-Great-Mother1.pdf

https://www.jstor.org/stable/40371806?seq=1\#page_scan_tab_contents

https://journals.openedition.org/lawrence/93

McCullough, Colleen. 1977. The Thorn Birds. Australia: Harper and Row

Murfin, Ross C. Sons and Lovers: A Novel of Division and Desire. Boston: Twayne Publishers, 1987.

Newmann, Erich. 1955. "The Great Mother: An Analysis of the Archetype, A Study of the Magna Mater" translated into English by Ralph Manheim. Princeton. 
Neumann, Erich and Ralph Manheim and Martin Liebscher. The Great Mother: An Analysis of the Archetype.Princeton: Princeton University Press, 2015. https://muse.jhu.edu/ (accessed August 2, 2019).

Rashkin, Esther. 1998. "Tools for a New Psychoanalytic Literary Criticism: The Work Of Abraham and Torok". Diacritics. John Hopkins University Press.

Worthen J. (1979). Sons and Lovers. In: D. H. Lawrence and the Idea of the Novel. Palgrave MacMillan, London.

\section{ABOUT THE AUTHOR}

Dr. Wahaj Unnisa Warda, Lecturer, Department of English, College of Science and Humanities, Prince Sattam Bin Abdulaziz University, Al-Kharj, Riyadh, Kingdom of Saudi Arabia. Is an English Language and Literature Instructor for both Bachelor's and Master's for the past twenty years. She is a member and reviewer of various national and international societies and has published more than twenty articles in international journals. 